\title{
Use of Disposed Agricultural Lands in LLC "Alliance-Agro" in the Sengileevsky District of the Ulyanovsk Region
}

\author{
Olga Tsapovskaya, Elena Provalova*, Yuri Ermoshkin, Nikolay Khvostov and Oksana Khamzina \\ Ulyanovsk State Agricultural University, Ulyanovsk, Russia
}

\begin{abstract}
The paper studies the issue of the use of disposed agricultural land through the example of LLC "Alliance-agro in Sengileevsky district of the Ulyanovsk region. The authors consider the grounds for cultural and technical work and provide the results of a survey of unused arable land on the farm. A technology for the development of disposed agricultural land is proposed. Everyone knows that agricultural land is of particular importance as a means of agricultural production and is the second largest category of land in the unified land fund of the Russian Federation in terms of area, which includes the best and fertile lands making up the heritage of the country. Despite the fact that the schemes for the use of agricultural land are developed, many questions of a theoretical, methodological and applied nature need to be improved, since this is associated with incessant changes in the legal and organizational systems of land use. As a result of irrational use of land, degradation, littering, overgrowing with trees and shrubs of agricultural areas occurs. These processes lead to the fact that fertile lands are withdrawn from circulation. Our research is aimed to solve the problems in the field of the improvement of the cadastral registration of lands, the process of the organization of rational land use, as well as the most effective use of unused lands overgrown with trees and shrubs. The solution to this problem will help the rational transformation of the agricultural land use system and increase in their efficiency. Moreover it will help to solve the problem of the involvement of unused land in agricultural production and increase the efficiency of cadastral registration of agricultural land. As a result of the land clearing proposed by the authors, the sites of this object will be put into agricultural circulation, where any zoned agricultural crop can be grown from the first year of development in case of a favorable water-air regime in the root layer and complex agrochemical cultivation.
\end{abstract}

\section{Introduction}

Agricultural lands, as the most valuable ones, are subject to special protection [1].

However, today the problem of the use of agricultural land is urgent. There is a reduction in the cultivated areas involved in agricultural activities. With $9 \%$ of the world's agricultural land and $55 \%$ of black soils, our country produces only slightly more than $1 \%$ of the gross domestic product of world agriculture. In addition, the use of arable land affects food security. From the cultivated areas in the Russian Federation, products ensuring internal food security by only $80 \%$ are obtained [8].

Modern scientists such as S.N. Volkov, V.N. Khlystun, A.A. Murasheva, E.V. Cherkashina and others pay a lot of attention to this issue in their works $[3,4,6,7]$.

The relevance of the research topic is explained by the need to solve problems in the field of the improvement of the cadastral registration of lands, as well as the most effective use of unused lands overgrown with trees and shrubs

According to the program "Development of agriculture and regulation of markets for agricultural products, raw materials and food in the Ulyanovsk region for 2014-2020" Alliance-Agro LLC is included in the register of agricultural producers, planning cultural and technical works in the Ulyanovsk region for 2016-2020.

\section{Materials And Research Methods}

The object of research is located in the Ulyanovsk region, the eastern part of the East European region, which is the most developed one in economical context. [2].

The development of design estimates and technological documentation for land clearing is specified in the Charter of the FSBI Station of the Agrochemical Service "Ulyanovskaya", approved by the Ministry of Agriculture of the Russian Federation under No. 323-u.

The survey of unused arable land in Alliance-Agro LLC was carried out in accordance with the List of the indicators of non-use of land plots for agricultural production, approved by Decree of the Government of the Russian Federation No. 369 dated April 23, 2012.

The calculation of the amount of time and equipment for cultural and technical events was made on the basis

\footnotetext{
* Corresponding author: provalova2013@yandex.ru
} 
of Collection No. 1 and No. 47 - State Elemental Estimated Standards for Construction Work (GESN2001) and SNiP 1.04.03-85.

According to regulatory documents:

- A tractor on a pneumatic wheel drive 96 (130) kW (hp) - T-150 performed skidding of wood, disking and plowing of soil;

- Tractors on pneumatic wheels 59 (80) $\mathrm{kW}$ (hp) MTZ-80, MTZ-82 performed removing of stumps from the plots, disking, cultivating the soil and rolling the soil.

The local cost estimate was compiled on the basis of the methodological instructions MDS81-35.2004. MDS81-33.2004, MDS81-25.2005, as well as on the collections of Territorial Estimated Standards (TES2001) in the edition of 2014 for objects financed from the budget of all levels and extra-budgetary funds. $[7,11]$

The additional expenses were taken from the payroll for the corresponding type of work on the basis of MDS81-33.2004 and the letter of the Federal Agency for Construction and Housing and Communal Services (State construction agency) dated November 27, 2012 No. 2536-IP / 12 / GS [10, 13].

The estimated profit was accepted from the payroll budget for the corresponding type of work on the basis of the letter of housing and communal services dated November 18, 2004 No. AP-5536/06 (to MDS 8125.2001).

\section{Results and discussion}

The area of the object is 242 hectares. The distribution of soils on the land plots of LLC "Alliance-Agro" in Sengileevsky district is presented in Table 1.

Table 1. Distribution of soils on land plots of LLC "AllianceAgro" in Sengileevsky district

\begin{tabular}{|c|c|c|c|}
\hline $\begin{array}{c}\text { No. of } \\
\text { site }\end{array}$ & $\begin{array}{c}\text { Land } \\
\text { area, ha }\end{array}$ & Soil & Structure \\
\hline 1 & 39 & $\begin{array}{c}\text { podzolized medium-humus } \\
\text { low-power black soil }\end{array}$ & heavy loamy \\
\hline 2 & 108 & $\begin{array}{c}\text { podzolized medium-humus } \\
\text { low-power black soil }\end{array}$ & heavy loamy \\
\hline 3 & 26 & leached thin black soil & light clay \\
\hline 4 & 10 & leached low-power black soil & light clay \\
\hline 5 & 46 & $\begin{array}{c}\text { leached medium-humus } \\
\text { medium-thick black soil }\end{array}$ & light clay \\
\hline 6 & 13 & $\begin{array}{c}\text { leached medium-humus } \\
\text { medium-thick black soil }\end{array}$ & light clay \\
\hline
\end{tabular}

General characteristics of the sites are presented in Table 2. The plots of land selected for land clearing, according to the act of selection of land plots, are arable land that has not been used for more than 7 years, overgrown with woody vegetation, shrubs and covered with sod. The agricultural lands selected for land clearing meet the requirements of the list of non-use of land plots.

In LLC "Alliance-Agro" the areas not used in circulation for a long time are overgrown with woody vegetation of soft species composition, as well as ashleaf maple, which is an aggressive woody weed that is difficult to destroy. It is primarily presented by cereal and aster plant species, among them creeping wheatgrass, canary grass, meadow bluegrass, awnless rump and wormwood.

Table 2. General characteristics of the land plots of LLC "Alliance-Agro" in Sengileevsky district

\begin{tabular}{|c|c|c|c|}
\hline No. & $\begin{array}{l}\text { Condition of land plots for } \\
\text { the selection period }\end{array}$ & $\begin{array}{c}\text { Land } \\
\text { area, } \\
\text { ha }\end{array}$ & $\begin{array}{c}\text { Agricultural } \\
\text { use of land } \\
\text { after land } \\
\text { clearing } \\
\end{array}$ \\
\hline 1 & $\begin{array}{l}\text { Land plot, cadastral number. } \\
\text { 73: 14: } 052101: 247 \text { with an } \\
\text { area of } 39 \text { hectares, not used } \\
\text { for more than } 7 \text { years, } \\
\text { overgrown with woody } \\
\text { vegetation, shrubs, sod }\end{array}$ & 39 & arable land \\
\hline 2 & $\begin{array}{l}\text { Land plot, cadastral number. } \\
\text { 73: } 14: 052101: 249 \text { with an } \\
\text { area of } 108 \text { hectares, not used } \\
\text { for more than } 7 \text { years, } \\
\text { overgrown with woody } \\
\text { vegetation, shrubs, sod }\end{array}$ & 108 & arable land \\
\hline 3 & $\begin{array}{l}\text { Land plot, cadastral number. } \\
\text { 73: 14: } 052101: 249 \text { with an } \\
\text { area of } 26 \text { hectares, not used } \\
\text { for more than } 7 \text { years, } \\
\text { overgrown with woody } \\
\text { vegetation, shrubs, sod }\end{array}$ & 26 & arable land \\
\hline 4 & $\begin{array}{l}\text { Land plot, cadastral number. } \\
\text { 73: 14: } 052101: 249 \text { with an } \\
\text { area of } 10 \text { hectares, not used } \\
\text { for more than } 7 \text { years, } \\
\text { overgrown with woody } \\
\text { vegetation, shrubs, sod }\end{array}$ & 10 & arable land \\
\hline 5 & $\begin{array}{l}\text { Land plot, cadastral number. } \\
\text { 73: 14: } 052101: 249 \text { with an } \\
\text { area of } 46 \text { hectares, not used } \\
\text { for more than } 7 \text { years, } \\
\text { overgrown with woody } \\
\text { vegetation, shrubs, sod }\end{array}$ & 46 & arable land \\
\hline 6 & $\begin{array}{l}\text { Land plot, cadastral number. } \\
\text { 73: 14: } 052101: 249 \text { with an } \\
\text { area of } 13 \text { hectares, not used } \\
\text { for more than } 7 \text { years, } \\
\text { overgrown with woody } \\
\text { vegetation, shrubs, sod }\end{array}$ & 13 & arable land \\
\hline
\end{tabular}

The condition of the selected plots corresponds to forested, bushy and soddy and requires serious processing. Therefore, during the selection of a set of machines and technology for land clearing, the type and texture of the soil, the degree of forest cover, the thickness of the fertile soil layer, the thickness and composition of the sod are taken into account.

One of the main requirements is the maximum preservation of the fertile soil layer at all stages of cultural and technical work, starting with the removal of woody vegetation and ending with primary soil cultivation.

According to the technological instructions, the project includes grub felling, skidding wood, setting up cutting areas, cutting wood obtained from felling trees, removing stumps manually, removing stumps with tractor trailers, disking on grubbed areas, plowing and 
subsequent disking of mineral soils, soil cultivation without harrowing and soil compaction. [3]

The technology for the development of forested, turfed and tussock areas is shown in Table 3.

The calculation of the amount of time and equipment for land clearing was made on the basis of Collection No. 1 and No. 47 - State Elemental Estimated Standards for Construction Work (GESN-2001) and SNiP 1.04.03-85.

According to regulatory documents:

- A tractor on a pneumatic wheel drive 96 (130) kW (hp) - T-150, performed wood dragging, disking, plowing of the soil;

- Tractors on pneumatic wheels 59 (80) kW (hp) MTZ-80, MTZ-82 carried out the removal of stumps from the plots, disking, soil cultivation and soil rolling.

The calculation of the amount of time and equipment for land clearing of Alliance-Agro is presented in Table 4.

The calculation of the need for time and technology was made based on the standards provided for the production of land clearing. The calculations were made according to the fact that the work will be carried out in 1 shift and seven days a week.

The volumes of cultural and technical measures by type of work are presented in Table 5.

The powerful sod is swept aside in almost all areas. As it is known, many turfed lands contain very few nutrients in a form assimilable for plants. As a result, the cultivated plants sown on the plowed sod are deficient in nitrogen and phosphorus in the first phases of development. Therefore, the system of cultivation of turfed lands should be aimed primarily at accelerated decomposition of the sealed turf and enrichment of the soil with basic nutrients in an accessible form. Therefore, when processing fallows and other soddy soils, the tasks are to deprive the sod of vitality, by repeated passes with a heavy disc harrow at an angle of 300 to the previous pass, thereby loosen the layer and create conditions for accelerated decomposition of sod and root residues.

Plowing of shrubs (small growth) on soils with a thickness of the humus layer exceeding the plowing depth is allowed. The introduction of wood into the balance of organic matter by grinding and mixing it with the soil along with leaves, roots, rhizomes and herbal vegetation most fully meets modern agrochemical requirements. The gap in time between plowing the bush and cutting the layer is unacceptable. The layer must be processed with heavy disc harrows in 3-4 passes, with the first two passes being done along and the next - at an angle (up to 300) to the plowing direction.

Table 3. Technology for the development of forested, turfed and tussock areas in Alliance-Agro

\begin{tabular}{|c|c|c|c|c|}
\hline \multirow{2}{*}{ Type of works } & \multicolumn{2}{|c|}{ Device } & \multirow{2}{*}{$\begin{array}{c}\text { Number of } \\
\text { trees, } \\
\text { thousand } \\
\text { pieces }\end{array}$} & \multirow[b]{2}{*}{$\begin{array}{c}\text { Area, } \\
\text { ha }\end{array}$} \\
\hline & Tractor & Tool & & \\
\hline $\begin{array}{l}\text { grub felling: soft } \\
\text { species, up to a } \\
\text { diameter of } 16 \mathrm{~cm}\end{array}$ & & Chainsaw & 10,648 & \\
\hline $\begin{array}{c}\text { Skidding wood: } \\
\text { diameter up to } 20 \mathrm{~cm}\end{array}$ & $\mathrm{~T}-150$ & $\begin{array}{l}\text { Rope-block } \\
\text { system }\end{array}$ & 10,648 & \\
\hline $\begin{array}{l}\text { Arrangement of } \\
\text { cutting sites }\end{array}$ & & Chainsaw & 10,648 & \\
\hline $\begin{array}{l}\text { Cutting wood } \\
\text { obtained from felling: } \\
\text { up to dia. } 12 \mathrm{~cm}\end{array}$ & & Manually & 10,648 & \\
\hline $\begin{array}{l}\text { Manual removal of } \\
\text { stumps: up to } 120 \\
\text { mm in diameter }\end{array}$ & & Manually & 10,648 & \\
\hline $\begin{array}{l}\text { Removal of stumps } \\
\text { with tractor trailers } 2 \mathrm{t} \text { : } \\
\text { diameter up to } 32 \mathrm{~cm}\end{array}$ & MB-82 & 2 PTS-4.5 & 10,648 & 726 \\
\hline $\begin{array}{l}\text { Disking on grubbed } \\
\text { areas, on soils: light } \\
\text { and medium } \\
\end{array}$ & $\mathrm{T}-150$ & BDM-4x4 & & 242 \\
\hline $\begin{array}{l}\text { Plowing in grubbed } \\
\text { areas }\end{array}$ & $\mathrm{T}-15 \mathrm{O}$ & PN-4 & & 484 \\
\hline $\begin{array}{l}\text { Disking of mineral } \\
\text { soils }\end{array}$ & MB-82 & BDM-4x4 & & 484 \\
\hline $\begin{array}{c}\text { Cultivation of the soil } \\
\text { without harrowing }\end{array}$ & MT3-80 & KPS-4 & & 242 \\
\hline
\end{tabular}

Table 4. Calculation of the amount of time and equipment for land clearing in Alliance-Agro

\begin{tabular}{|c|c|c|c|c|c|c|c|}
\hline Tractor & Tool & $\begin{array}{c}\text { Labor costs, man } \\
\text { hour 1 ha }\end{array}$ & $\begin{array}{c}\text { Number of } \\
\text { trees, thousand } \\
\text { pieces area, ha }\end{array}$ & $\begin{array}{c}\text { Number of } \\
\text { hours }\end{array}$ & $\begin{array}{c}\text { Number of } \\
\text { days }\end{array}$ & $\begin{array}{c}\text { Number of } \\
\text { tractors, } \\
\text { people }\end{array}$ & $\begin{array}{c}\text { Number of } \\
\text { months }\end{array}$ \\
\hline & Chainsaw & 5.21 & 10.648 & 55.5 & 5.55 & 4 & 0.04 \\
\hline T-150 & $\begin{array}{c}\text { Rope-block } \\
\text { system }\end{array}$ & 25.62 & 10.648 & 272.8 & 27.28 & 4 & 0.23 \\
\hline & Chainsaw & 2.11 & 10.648 & 22.46 & 2.24 & & 0.01 \\
\hline & Manually & 6.4 & 10.648 & 68.1 & 6.81 & 4 & 0.05 \\
\hline & Manually & 3.3 & 10.648 & 35.1 & 3.55 & 4 & 0.02 \\
\hline T-150 & BD-4x4 & 0.89 & 726 & 646.2 & 6.46 & 4 & 0.05 \\
\hline T-150 & PN-8-35 & 4.38 & 242 & 1059.9 & 105.9 & 4 & 0.88 \\
\hline MTZ-80 & BD-4x4 & & 484 & 532.4 & 53.2 & 4 & 0.44 \\
\hline MTZ-80 & KPG-4 & 0.51 & 484 & 246.8 & 24.68 & 2 & 0.41 \\
\hline MTZ-80 & ZKKSH-B & 0.9 & 242 & 217.8 & 21.78 & 2 & 0.36 \\
\hline Total & & & & 3211.66 & 262.91 & & 2.58 \\
\hline
\end{tabular}


Table 5. Volumes of cultural and technical measures by type of work

\begin{tabular}{|c|c|c|c|c|c|c|c|c|c|c|c|}
\hline $\begin{array}{l}\dot{\bar{d}} \\
\bar{\Xi} \\
\mathbf{Z}\end{array}$ & 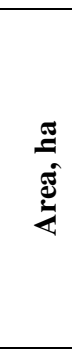 & 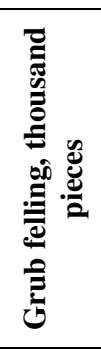 & 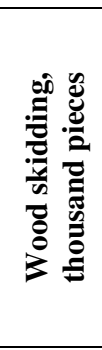 & 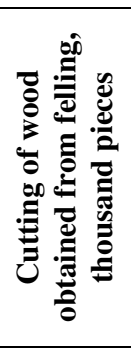 & 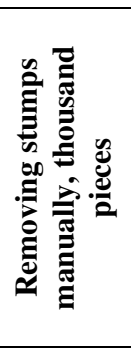 & 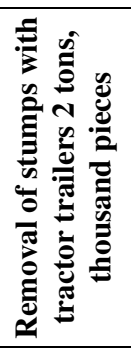 & 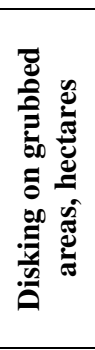 & 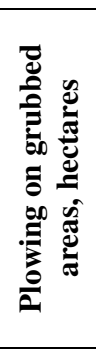 & 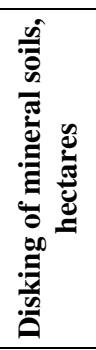 & 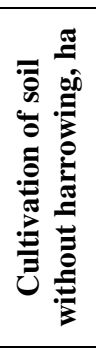 & 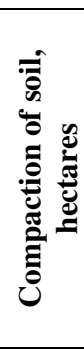 \\
\hline 1 & 39 & 1.13 & 1.13 & 1.13 & 1.13 & 1.13 & 117 & 39 & 78 & 78 & 39 \\
\hline 2 & 108 & 5.40 & 5.40 & 5.40 & 5.40 & 5.40 & 324 & 108 & 216 & 216 & 108 \\
\hline 3 & 26 & 0.98 & 0.98 & 0.98 & 0.98 & 0.98 & 78 & 26 & 52 & 52 & 26 \\
\hline 4 & 10 & 0.33 & 0.33 & 0.33 & 0.33 & 0.33 & 30 & 10 & 20 & 20 & 10 \\
\hline 5 & 46 & 2.45 & 2.45 & 2.45 & 2.45 & 2.45 & 138 & 46 & 92 & 92 & 46 \\
\hline 6 & 13 & 0.37 & 0.37 & 0.37 & 0.37 & 0.37 & 39 & 13 & 26 & 26 & 13 \\
\hline Total & 242 & 10.65 & 10.65 & 10.65 & 10.65 & 10.65 & 726 & 242 & 484 & 484 & 242 \\
\hline
\end{tabular}

During cultivation, a loose layer is formed on the surface of arable land, which prevents the evaporation of water from the root layer. As a result, the water and air regimes of the soil are improved, microbiological activity and the mobilization of nutrients are enhanced. The compaction of the treated soil with rollers is provided in order to ensure better decomposition of root residues.

When carrying out land clearing, all measures should be aimed to bring the cultivated agricultural lands to the state of cultivation and maximize the preservation of the natural fertility of soils: matching the depth of plowing to the thickness of the arable horizon, incorporating plant residues and loosening the topsoil [5].

\section{Conclusion}

According to the program "Development of agriculture and regulation of markets for agricultural products, raw materials and food in the Ulyanovsk region for 20142020" LLC “Alliance-Agro" was included in the register of agricultural producers planning to involve in turnover of disposed agricultural land by land clearance in the Ulyanovsk region for 2016-2020. The area of the object was 242 hectares.

The land plots selected for clearing, according to the act of selection of land plots, were arable land unused for more than 7 years, overgrown with woody vegetation, shrubs and covered with sod.

The complex of works on the involvement of disposed agricultural land into circulation includes organizational, technological and clearing activities.

The development of design estimates and technological documentation land clearing is specified in the Charter of the Federal State Budgetary Institution "Station of the Agrochemical Service "Ulyanovskaya", approved by the Ministry of Agriculture of the Russian Federation under No. 323-u.

One of the main requirements is the maximum preservation of the fertile soil layer at all stages of cultural and technical work, starting with the removal of woody vegetation and ending with primary soil cultivation.
According to the technological instructions, the project includes grub felling, skidding wood, setting up cutting areas, cutting wood obtained from felling trees, removing stumps manually, removing stumps with tractor trailers, disking on grubbed areas, plowing and subsequent disking of mineral soils, soil cultivation without harrowing and soil compaction.

\section{References}

1. Russian Federation, On land management, Federal Law of July 18, 2005, no. 78-FL (as amended on December 31, 2017) (Legal System Consultant Plus)

2. General plan of the municipal district Sengileevsky in Ulyanovsk region, Explanatory note in 2 volumes (Institute of Urban Studies, St. Petersburg, 2016), $149 \mathrm{p}$.

3. S.N. Volkov, State and development prospects of the land management industry in the Russian Federation, Land manag., cadaster and monitor. of lands., 7(186), 5-14 (2020)

4. S.N. Volkov, E.S. Kievskaya, Z.A. Volkova, N.G. Konokotin, Economic mechanism for regulating the use of agricultural land in the USA, Land manag., cadaster and monitor. of lands, 6(90), 32-41 (2012)

5. N.V. Khvostov, E.V. Provalova, S.E. Erofeev, E.V. Bannikova, Yu.A. Mokshina, The project of on-farm land management for the rational use of lands of regional state unitary agricultural enterprise Staromainskaya of the Staromainsky district of the Ulyanovsk region, Land manag., cadaster and monitor. of lands, 4, 274-283 (2021)

6. V.N. Khlystun, A.A. Murasheva, V.M. Stolyarov, Conceptual approaches to the development and implementation of a program for involving unused agricultural land into circulation, Econ. of agricult. and proc. enterpr., 5, 2-11 (2020)

7. E.V. Cherkashina, O. A. Sorokina, I.V. Fomkin, A.V. Fedorinov, L.E. Petrova, Identification of unused agricultural lands and their involvement in 
economic circulation on the basis of a planned land inventory, Land manag., cadaster and land monitor., 1, 48-54 (2020)
8. E.V. Provalova, M.N. Lukyanova, O.V. Skrobotova, R.M. Ivanova, Prospects for the development of ecological tourism in specially protected natural areas of the Ulyanovsk region, J. of envir. Manag. and tourism, 4, 809-818 (2019) 